\title{
Relationship between daily dietary fructose intake, body composition and biochemical parameters patients with type 2 diabetes
}

\author{
Sabriye Arslan ${ }^{1}$ \\ Nevin Sanlier ${ }^{2}$
}

\begin{abstract}
Purpose: This study was carried out to determine the relationship of daily dietary fructose intake with body composition and some biochemical parameters in individuals with diabetes.

Method and material: A total of 156 individuals with diabetes, 53 men and 103 women, between the ages of 30 and 65 ( $\bar{x}=51 \pm 8.59$ years old) participated in the study. Research data was obtained through face-to-face interviews conducted by the researcher using a questionnaire, which included general information, dietary habits, daily food consumption record.

Results: The fructose intake of the men was $13.2 \pm 12.09 \mathrm{~g} /$ day and that of the women was $13.6 \pm 11.10 \mathrm{~g} /$ day $(\mathrm{p}>0.05)$. The ratios of the daily dietary energy intake from fructose were $7.4 \pm 5.56 \%$ and $7.4 \pm 5.34 \%$ in men and women, respectively. It was determined that the individuals consuming the highest levels of fructose (Q4) had higher BMI, waist circumference and average visceral fat, serum VLDL-C, HbA1c levels and lower serum HDL-C levels than the individuals consuming the lowest levels of fructose (Q1). It was observed that Q4 obtain higher levels of energy, carbohydrates and fat than Q1 $(\mathrm{p}<0.05)$. Prevalence of obesity was found to be the lowest $(59.0 \%)$ in the group intake the lowest levels of fructose and the highest $(64.1 \%)$ in the group intake the highest levels of fructose $(\mathrm{p}>0.05)$.

Conclusion: Further studies are needed to develop more specific suggestions regarding fructose intake and to better understand the relationship between fructose intakes, body composition and biochemical parameters in individuals with type 2 diabetes.
\end{abstract}

Keywords: Diabetes; Fructose; Obesity; High Fructose Corn Syrup; Diet.

\section{Introduction}

Diabetes results from deficiency in the production of insulin in the body or the development of insensitivity of the cells to insulin (Chiavaroli et al., 2014) . Considering global estimates, experts expect the number of people with diabetes will reach 48.3 million worldwide in 2050 (Sheehy et al., 2009). This increase in diabetes is attributed to the decrease in physical activity and the increase in obesity (Chiavaroli et al., 2014). Intake of some nutrients such as fructose as well as excess energy intake is also thought to cause the development of diabetes. In the past, fructose intake was provided by fruits and honey etc which is contain high fructose, and daily intake was between 16 and $20 \mathrm{~g}$. However, daily fructose intake has increased up to 85-100 g in the last 30 years due to the addition of sugar (sucrose, high fructose corn syrup (HFCS),

\footnotetext{
1 M.Sc., Gazi University, Faculty of Health Sciences, Department of Nutrition and Dietetics, Besevler/ANKARA/TURKEY, sabriyebolluk@,hotmail.com

2 Prof. Dr., Gazi University, Faculty of Health Sciences, Department of Nutrition and Dietetics,Besevler/ANKARA/TURKEY, ntekgul@gazi.edu.tr, nevintekgul@gmail.com
} 
Arslan, S., \& Sanlier, N. (2016). Relationship between daily dietary fructose intake, body composition and biochemical parameters patients with type 2 diabetes. Journal of Human Sciences, 13(2), 2642-2655. doi:10.14687/jhs.v13i2.3737

honey, molasses and other syrups) to carbonated beverages, fruit juices, canned fruits, bakery products and jams (Basciano et al., 2005; Bray, 2008). Commercially HFCS contain either $42 \%$ or $55 \%$ fructose, and $55 \%$ type is used more (55\% fructose, $42-44 \%$ glucose, $1-3 \%$ polysaccharide) (Forshee et al., 2007). Commercially HFCS is a stronger sweetener than sucrose and it is preferred by food manufacturers because it is cheaper, does not crystallize quickly and has a flavour-enhancing effect (Neilson, 2007). One of the causes of obesity and metabolic syndrome is the excessive consumption of sugar added products particularly those containing fructose (Schulze et al., 2004; Hossain et al., 2007). Recent studies indicate that the increase in fructose intake runs in parallel with the increase in the number of people with obesity and type 2 diabetes (Johnson et al., 2007; Goran et al., 2013). In addition, excessive fructose intake is reported to be associated with diseases such as hypertension, hyperlipidemia, non-alcoholic steatohepatitis and gout (Wang et al., 2012; White, 2013).

The metabolism of fructose operates differently than that of glucose (Gaby, 2005). Fructose is transported into the intestinal cells via GLUT-5 which is a specific fructose transporter. Being Na-independent, this process does not require energy. Fructose absorbed in the intestinal cells is then released into the bloodstream via the GLUT2 transporters in the enterocyte basolateral membrane. A portion of the fructose in the enterocytes is converted into lactate while another portion is converted into glucose via triose phosphate. The main target organ of the fructose in the bloodstream is the liver (Feinman \& Fine, 2013). This step is the basic difference between the metabolisms of glucose and fructose. Phosphofructokinase, which is a regulatory enzyme, takes part when glucose is metabolized. Fructose, on the other hand, bypasses this regulatory step and passes directly through the glycolytic pathway step. Since fructose metabolism cannot be regulated at this stage, it causes the production of a large amount of glycolysis product which leads to an increase in the synthesis of fatty acids. Fructose is phosphorylated without entering the glycolytic pathway and unlike glucokinase, fructokinase cannot be regulated by insulin. Increased synthesis of fatty acids may increase the fatty acids and adipose in the circulation. This, depending on the development of fatty acids in tissues other than the adipose tissue, may lead to lipotoxicity which reduces the insulin sensitivity of cells (Neilson, 2007). Insulin secretion of the pancreatic cells affected by fructose-induced lipotoxicity may decrease (Stephan et al., 2010). It is also stated that fructose cannot stimulate leptin secretion sufficiently and cannot suppress ghrelin secretion which in turn increases appetite and decreases satiety (Johnson et al., 2007). Therefore, excessive fructose intake can lead to excessive energy intake and hence weight gain (Stephan et al., 2010).

Although the effects of fructose on individuals with diabetics are not very clear, diabetic patients have the impression that it can be a therapeutic tool in their diet because its glycemic index is low and it does not require insulin in its metabolism (Crapo et al., 1981; Mayes, 1993). In addition, it has also been reported that fructose has a positive effect in that it increases energy expenditure in obese individuals with or without diabetes (Tappyet al., 1986; Simonson et al., 1988). However, fructose is given a separate place in diabetes guidelines due to its effect on lipids. It is stated in ADA guidelines that when starch and sucrose are replaced by fructose in a diet, it generates a lower glycemic response and while doing that, fructose shows no adverse effect on lipids (Bantle et al., 2008). However, it has also been reported in a study that fructose has a detrimental effect on insulin resistance when it replaces starch in a 5-week long diet in which $15 \%$ of the daily energy is taken/intake from fructose (Hallfrisch et al., 1983).

For these reasons, this study was planned and carried out in order to determine the relationship between daily fructose intake, body composition and some biochemical parameters in individuals with type 2 diabetes. 
Arslan, S., \& Sanlier, N. (2016). Relationship between daily dietary fructose intake, body composition and biochemical parameters patients with type 2 diabetes. Journal of Human Sciences, 13(2), 2642-2655. doi:10.14687/jhs.v13i2.3737

\section{Method and Materials}

\subsection{Participants}

This study was carried out at Gazi University Hospital in the department of Endocrinology and Metabolism. The participants were randomly selected from patients with type 2 diabetes who applied to the clinic between January 2014-January 2015. Patients (103 females, 53 males) between the ages of 30 and 65 years old. Participants signed a voluntary participation form which adhered to Declaration of Helsinki protocols. Pregnant women, lactating women, those with hormonal disease, type-1 diabetes and oncological diseases were excluded from the study.

Committee approval from Gazi University Ethics Commission was obtained for this study.

\subsection{Dietary assement}

Research data were collected through face-to-face interviews conducted by the researcher using a questionnaire developed by the researchers. The frequency of the participants' food consumption was recorded in order to determine the amount of fructose they consume daily. The Fructose Frequency Form includes items containing nutrients such as energizing soft drinks, sodas and fruit juices, and some fructose-rich fruits and vegetables. The food consumption of the participants was determined by making a record of food consumption for 3 days ( 1 weekend day, 2 weekdays). The amount and content of all the foods consumed by the individuals was written down on the food consumption record form. Gram quantities of the foods listed in the food consumption records were calculated using the "Food and Nutrition Photo Catalogue: Size and Quantity" (Rakıcioğlu et al., 2012). The Nutrition Information Systems program was used for daily energy and nutrients provided by the quantity of food consumed (Bebis, 2004).

\subsection{Anthropometric measurements}

The participants' body weight, body fat mass, fat free mass, water mass and body fat percentage were measured using a Tanita BC $545 \mathrm{~N}$ portable bioelectrical impedance device (BIA). Anthropometric measurements were taken by trained dieticians and with participants wearing light clothes and no shoes. A portable scale was used to measure body weight to the nearest half-kilogram. Height was measured to the nearest $0.1 \mathrm{~cm}$ with a wall-mounted stadiometer. Waist circumference (WC) was measured above the iliac crest and below the lowest rib margin at minimum respiration. Hip circumference (HC) was measured at the widest part of the hip at the level of the greater trochanter to the nearest half-centimeter. The waist and hip circumferences were measured with a tape (Pekcan, 2008).

Body mass index (BMI) was calculated by dividing body weight by the square meter of the height (Body weight $(\mathrm{kg}) /$ height $\left.(\mathrm{m})^{2}\right)$. The evaluation of body mass index was based on the classification of the World Health Organization (WHO, 2000).

\subsection{Biochemical Parameters}

Biochemical parameters routinely checked at the hospital (fasting plasma glucose, HbA1c, total cholesterol (TC), high-density lipoprotein cholesterol (HDL-C), low-density lipoprotein cholesterol (LDL-C), triglycerides (TG)) were evaluated based on the patient files. Fasting plasma lipids and concentrations of TG, HDL-C and total TC were analysed and LDL-C concentrations were calculated. Early morning venous blood samples were obtained from each participant for 
Arslan, S., \& Sanlier, N. (2016). Relationship between daily dietary fructose intake, body composition and biochemical parameters patients with type 2 diabetes. Journal of Human Sciences, 13(2), 2642-2655. doi:10.14687/jhs.v13i2.3737

biochemical screening tests, following a twelve-hour overnight fast. Professional staff performed venipuncture by using vacutainers to obtain $15 \mathrm{~mL}$ of whole blood. Blood was centrifuged for plasma separation at government hospitals where the actual biochemical analyses were performed.

\subsection{Statistical Analysis}

Statistical analyses were performed using SPSS version 16.0 software package. Descriptive analyses were made with mean \pm standard deviation and median \pm IQR (interquartile range from widths). Frequencies and percentages were used for nominal variables. The Chi-square test was carried out for between group difference, and the Mann-Whitney $U$ test was used for pairwise comparisons. Relationships between variables were analyzed using the Spearman's rank correlation coefficient, classification (hazard) situations were grouped according to odds ratios obtained from logistic regression, fructose intake was grouped as quarters (Q1, Q2, Q3, Q4) and between group difference was determined by the ANOVA and Tukey test. Significance was evaluated at $\mathrm{p}<0.05$ level.

\section{Results}

This study was conducted on a total of 156 individuals with type 2 diabetes, 53 men and 103 women, between the ages of 30 and 65 . The average age of the male subjects who participated in the study was $50.36 \pm 8.27$ years while that of the female subjects was $51.5 \pm 8.59$ years. The mean duration of diagnosis of diabetes was $5.6 \pm 5.64$ years for the men and $6.1 \pm 6.89$ for the women. $90.4 \%$ of the individuals received pharmacological treatment for blood glucose regulation. $34.4 \%$ of these individuals received oral antidiabetics, $22 \%$ received insulin and $53.8 \%$ received both insulin and antidiabetics (data was not shown).

The daily fructose intake values of the men and women were $13.2 \pm 12.09 \mathrm{~g}$ and $13.6 \pm 11.10 \mathrm{~g}$, respectively $(\mathrm{p}>0.05)$. It was determined that the ratios of the daily dietary energy from fructose were $7.4 \pm 5.56 \%$ and $7.4 \pm 5.34 \%$ in men and women, respectively. It was determined that the amount of sucrose $(11.7 \pm 16.11 \mathrm{~g})$ the male participants received from their daily diet was lower than that $(12.4 \pm 13.95 \mathrm{~g})$ of the female participants $(\mathrm{p}>0.05)$. The ratios of the total energy received from sucrose in the daily diet were $2.2 \pm 2.82 \%$ and $3.2 \pm 3.49 \%$ in men and women, respectively (Table 1).

Table 1. Daily fructose and sucrose intake according to gender of the participants

\begin{tabular}{lllll}
\hline & Male (n:53) & Female (n:103) & & \\
& M \pm IQR & M \pm IQR & t & $\mathrm{p}$ \\
\hline Fructose (g) & $13.2 \pm 12.09$ & $13.6 \pm 11.10$ & 0.353 & 0.724 \\
Fructose (TE\%) & $7.4 \pm 5.56$ & $7.4 \pm 5.34$ & -0.326 & 0.745 \\
Fructose (CHO\%) & $3.2 \pm 2.41$ & $3.2 \pm 2.40$ & 0.435 & 0.664 \\
Sucrose (g) & $11.7 \pm 16.11$ & $12.4 \pm 13.95$ & -0.775 & 0.440 \\
Sucrose (TE\%) & $2.2 \pm 2.82$ & $3.2 \pm 3.49$ & -1.324 & 0.188 \\
Sucrose (CHO\%) & $5.9 \pm 6.08$ & $7.2 \pm 7.40$ & -1.369 & 0.173 \\
\hline
\end{tabular}

It was determined that the individuals consuming the highest levels of fructose (Q4) had higher BMI, waist circumference and the average visceral fat, VLDL-C, HbA1c levels and lower HDL-C levels than individuals consuming the lowest levels of fructose (Q1) ( $\mathrm{p}>0.05)$. It was detected that individuals of Q4 obtained higher levels of energy, carbohydrates and protein than those individuals of Q1 ( $<<0.05$, Table 2$)$. 
Arslan, S., \& Sanlier, N. (2016). Relationship between daily dietary fructose intake, body composition and biochemical parameters patients with type 2 diabetes. Journal of Human Sciences, 13(2), 2642-2655. doi: $10.14687 /$ ihs.v13i2.3737

Table 2. Anthropometric measurements, biochemical parameters and macro nutrient intakes of the individuals based on their fructose intake groups

\begin{tabular}{|c|c|c|c|c|c|c|c|}
\hline & $\begin{array}{c}\mathbf{Q 1}^{\mathrm{a}} \\
\bar{X} \pm \mathrm{SS}\end{array}$ & $\begin{array}{c}\mathrm{Q} 2^{\mathrm{b}} \\
\bar{X} \pm \mathrm{SS}\end{array}$ & $\begin{array}{c}\mathbf{Q 3}^{\mathrm{c}} \\
\bar{X} \pm \mathrm{SS}\end{array}$ & $\begin{array}{c}\mathbf{Q}^{\mathrm{d}} \\
\bar{X} \pm \mathrm{SS}\end{array}$ & $\mathbf{F}$ & $\mathrm{p}$ & $\begin{array}{c}\text { Tukey } \\
\text { test }\end{array}$ \\
\hline BMI $\left(\mathrm{kg} / \mathrm{m}^{2}\right)$ & $32.0 \pm 6.09$ & $31.8 \pm 5.56$ & $30.1 \pm 4.76$ & $32.9 \pm 5.82$ & 1.706 & 0.168 & - \\
\hline $\begin{array}{l}\text { Waist } \\
\text { circumference } \\
(\mathrm{cm})\end{array}$ & $97.7 \pm 9.21$ & $98.0 \pm 8.11$ & $94.4 \pm 13.30$ & $99.0 \pm 16.76$ & 0.787 & 0.503 & - \\
\hline $\begin{array}{l}\text { Hip } \\
\text { circumference } \\
(\mathrm{cm})\end{array}$ & $110.0 \pm 11.19$ & $109.9 \pm 8.56$ & $105.7 \pm 12.68$ & $111.3 \pm 13.87$ & 1.704 & 0.169 & - \\
\hline Visceral fat & $10.5 \pm 3.13$ & $11.4 \pm 4.72$ & $10.6 \pm 6.54$ & $11.9 \pm 2.66$ & 0.834 & 0.477 & - \\
\hline $\begin{array}{l}\text { Fasting plasma } \\
\text { glucose }(\mathrm{mg} / \mathrm{dL})\end{array}$ & $149.2 \pm 61.47$ & $158.1 \pm 64,12$ & $144.2 \pm 53.43$ & $149.8 \pm 52.73$ & 0.386 & 0.763 & - \\
\hline TG (mg/dL) & $199.3 \pm 187.68$ & $182.8 \pm 76,53$ & $162.8 \pm 74.52$ & $187.1 \pm 114.84$ & 0.599 & 0.616 & - \\
\hline $\mathrm{TC}(\mathrm{mg} / \mathrm{dL})$ & $200.3 \pm 38.18$ & $204.2 \pm 38,72$ & $188.9 \pm 46.35$ & $191.9 \pm 33.76$ & 1.263 & 0.289 & - \\
\hline LDL-C (mg/dL) & $123.8 \pm 32.46$ & $126.8 \pm 35,15$ & $111.7 \pm 34.88$ & $113.3 \pm 30.29$ & 1.997 & 0.117 & - \\
\hline $\begin{array}{l}\text { VLDL-C } \\
(\mathrm{mg} / \mathrm{dL})\end{array}$ & $29.8 \pm 10.28$ & $35.4 \pm 12.39$ & $31.7 \pm 12.03$ & $34.6 \pm 12.76$ & 1.862 & 0.138 & - \\
\hline HDL-C (mg/dL) & $46.6 \pm 10.36$ & $43.1 \pm 10.14$ & $46.4 \pm 12.27$ & $45.5 \pm 7.76$ & 0.946 & 0.420 & - \\
\hline HbA1c $(\%)$ & $7.2 \pm 1.71$ & $7.5 \pm 1.56$ & $7.3 \pm 1.73$ & $7.5 \pm 1.72$ & 0.281 & 0.839 & - \\
\hline Energy (kcal/day) & $1709.6 \pm 408.69$ & $1652.2 \pm 354.87$ & $1806.4 \pm 389.80$ & $1990.7 \pm 505.58$ & 4.899 & $0.003^{*}$ & $\begin{array}{l}(\mathrm{a}-\mathrm{d}) \\
(\mathrm{b}-\mathrm{d})\end{array}$ \\
\hline $\begin{array}{l}\text { Carbohydrates } \\
\text { (g/day) }\end{array}$ & $187.8 \pm 71.48$ & $166.1 \pm 48.58$ & $197.9 \pm 48.28$ & $228.1 \pm 74.52$ & 6.744 & $0.000^{*}$ & $\begin{array}{l}(\mathrm{a}-\mathrm{d}) \\
(\mathrm{b}-\mathrm{d})\end{array}$ \\
\hline Protein (g/day) & $59.2 \pm 16.64$ & $66.1 \pm 18.95$ & $68.5 \pm 22.25$ & $72.00 \pm 18.94$ & 3.046 & $0.031 *$ & $(\mathrm{a}-\mathrm{d})$ \\
\hline Fat (g/day) & $79.0 \pm 20.74$ & $78.3 \pm 24.32$ & $80.0 \pm 27.04$ & $84.32 \pm 29.66$ & 0.434 & 0.729 & - \\
\hline $\begin{array}{l}\text { Cholesterol } \\
\text { (mg/day) }\end{array}$ & $226.5 \pm 119.71$ & $234.2 \pm 125.21$ & $255.0 \pm 146.18$ & $307.61 \pm 220.72$ & 2.083 & 0.105 & - \\
\hline
\end{tabular}

${ }_{\mathrm{p}}<0,05, \mathrm{Q}_{1}$ : 1. Quartile, $\mathrm{Q}_{2}: 2$. Quartile $\mathrm{Q}_{3}: 3$. Quartile $\mathrm{Q}_{4}: 4$. Quartile TG= triglyceride, TC=total cholesterol, LDL$\mathrm{C}=$ low density lipoprotein cholesterol, VLDL-C = very low density lipoprotein cholesterol, HDL-C= high density lipoprotein cholesterol

Fructose intake of overweight individuals is $14.74 \pm 8.06 \mathrm{~g}$ while that of individuals with normal weight is $13.33 \pm 8.03 \mathrm{~g}$; therefore, the difference is not statistically significant $(\mathrm{p}>0.05)$ (Table 3).

Table 3. Fructose consumption of individuals depending on BMI classification

\begin{tabular}{lccccc}
\hline & $\begin{array}{c}\text { Normal } \\
\text { weight } \\
\overline{\boldsymbol{X}} \pm \mathbf{S S}\end{array}$ & Overweight & Obese & & \\
& $13.3 \pm 8.03$ & $\overline{\boldsymbol{X}} \pm \mathbf{S S}$ & $\overline{\boldsymbol{X}} \pm \mathbf{S S}$ & $\mathbf{F}$ & $\mathbf{p}$ \\
\hline Fructose $(\mathrm{g})$ & $9.3 \pm 6.49$ & $8.1 \pm 4.32$ & $7.4 \pm 3.81$ & 1.16 & 0.318 \\
Fructose $(\mathrm{TE} \%)$ & $3.5 \pm 1.89$ & $3.4 \pm 1.88$ & $3.2 \pm 1.74$ & 0.26 & 0.772 \\
Fructose $(\mathrm{CHO} \%)$ & & &
\end{tabular}

Prevalence of obesity is $59.0 \%$ in the group with the lowest daily fructose intake while $64.1 \%$ in the group with the highest daily fructose intake (Table 4). 
Arslan, S., \& Sanlier, N. (2016). Relationship between daily dietary fructose intake, body composition and biochemical parameters patients with type 2 diabetes. Journal of Human Sciences, 13(2), 2642-2655. doi:10.14687/jhs.v13i2.3737

Table 4. The distribution of BMI and biochemical parameters compared to reference values based on the fructose intake of the groups

\begin{tabular}{|c|c|c|c|c|c|c|c|}
\hline \multirow[b]{2}{*}{ Variables } & & Q1 & Q2 & Q3 & Q4 & \multirow[b]{2}{*}{$\mathrm{X}^{2}$} & \multirow[b]{2}{*}{$\mathrm{p}$} \\
\hline & & $\%$ & $\%$ & $\%$ & $\%$ & & \\
\hline \multirow{3}{*}{ BMI $\left(\mathrm{kg} / \mathrm{m}^{2}\right)$} & Normal weight & 7.7 & 7.7 & 7.9 & 5.1 & \multirow{3}{*}{1.78} & \multirow{3}{*}{0.94} \\
\hline & Overweight & 33.3 & 33.3 & 42.1 & 30.8 & & \\
\hline & Obese & 59.0 & 59.0 & 50.0 & 64.1 & & \\
\hline \multirow{2}{*}{$\mathrm{TC}(\mathrm{mg} / \mathrm{dL})$} & $<200$ & 56.4 & 51.3 & 64.1 & 69.2 & \multirow{2}{*}{3.11} & \multirow{2}{*}{0.38} \\
\hline & $\geq 200$ & 43.6 & 48.7 & 35.9 & 30.8 & & \\
\hline \multirow{2}{*}{ LDL-C (mg/dL) } & $<130$ & 61.5 & 61.5 & 76.9 & 76.9 & \multirow{2}{*}{4.33} & \multirow{2}{*}{0.23} \\
\hline & $\geq 130$ & 38.5 & 38.5 & 23.1 & 23.1 & & \\
\hline \multirow{2}{*}{ HDL-C (mg/dL) } & $<30$ & 7.7 & 12.8 & 5.1 & 2.6 & \multirow{2}{*}{3.42} & \multirow{2}{*}{0.34} \\
\hline & $\geq 30$ & 92.3 & 87.2 & 94.9 & 97.4 & & \\
\hline \multirow{2}{*}{$\mathrm{TG}(\mathrm{mg} / \mathrm{dL})$} & $<150$ & 44.7 & 33.3 & 53.8 & 38.5 & \multirow{2}{*}{3.73} & \multirow{2}{*}{0.29} \\
\hline & $\geq 150$ & 55.3 & 66.7 & 46.2 & 61.5 & & \\
\hline Fasting plasma glucose $(\mathrm{mg} / \mathrm{dL})$ & $>140$ & 100.0 & 100.0 & 100.0 & 100.0 & - & - \\
\hline
\end{tabular}

Q1: 1. Quartile, Q2: 2. Quartile Q3: 3. Quartile Q4: 4.Quartile

It was determined that fructose intake was not significantly correlated with any parameters (Table 5).

Table 5. The correlation between the fructose consumption of the individuals and anthropometric measurements and biochemical parameters ( $r$ )

\begin{tabular}{lcccccc}
\hline & \multicolumn{2}{c}{ Fructose $\mathbf{( g )}$} & \multicolumn{2}{c}{ Fructose $\mathbf{( C H O}$ \%) } & \multicolumn{2}{c}{ Fructose (TE\%) } \\
& $\mathbf{r}$ & $\mathbf{p}$ & $\mathbf{r}$ & $\mathbf{p}$ & $\mathbf{r}$ & $\mathbf{p}$ \\
\hline Body weight $(\mathrm{kg})$ & 0.022 & 0.790 & -0.148 & 0.065 & -0.123 & 0.128 \\
BMI (kg/m²) & 0.069 & 0.396 & -0.125 & 0.122 & -0.045 & 0.582 \\
Waist circumference (cm) & 0.028 & 0.728 & -0.091 & 0.256 & -0.030 & 0.713 \\
Hip circumference (cm) & 0.047 & 0.561 & -0.096 & 0.233 & -0.015 & 0.857 \\
Waist/hip ratio & -0.043 & 0.598 & -0.045 & 0.579 & -0.048 & 0.548 \\
\hline Body water (\%) & 0.040 & 0,621 & 0.063 & 0.431 & 0.036 & 0.658 \\
Muscle Mass (kg) & -0.023 & 0.778 & -0.089 & 0.267 & -0.111 & 0.166 \\
Body fat (\%) & 0.119 & 0.139 & -0.021 & 0.792 & 0.072 & 0.374 \\
Visceral fat & 0.073 & 0.368 & -0.055 & 0.496 & 0.006 & 0.940 \\
\hline TG (mg/dL) & -0.006 & 0.944 & -0.023 & 0.777 & -0.011 & 0.890 \\
TC (mg/dL) & -0.079 & 0.326 & -0.046 & 0.566 & -0.071 & 0.377 \\
LDL-C (mg/dL) & -0.129 & 0.110 & -0.048 & 0.552 & -0.099 & 0.221 \\
VLDL-C (mg/dL) & 0.117 & 0.145 & 0.083 & 0.301 & 0.114 & 0.158 \\
HDL-C (mg/dL) & 0.006 & 0.942 & -0.041 & 0.607 & 0.008 & 0.920 \\
\hline
\end{tabular}

No statistically significant difference was found between the group consuming high levels of fructose and the group consuming low levels of fructose, in terms of obesity ( $p>0.05$ ) (Table $6)$. 
Arslan, S., \& Sanlier, N. (2016). Relationship between daily dietary fructose intake, body composition and biochemical parameters patients with type 2 diabetes. Journal of Human Sciences, 13(2), 2642-2655. doi:10.14687/jhs.v13i2.3737

Table 6. The relationship between fructose intake and risk of obesity

\begin{tabular}{cccccc}
\hline & $\mathbf{B M I}<\mathbf{3 0} \mathbf{~ k g} / \mathbf{m}^{\mathbf{2}}$ & $\mathbf{B M I} \geq \mathbf{3 0} \mathbf{~ k g} / \mathbf{m} \mathbf{2}$ & Total & $\mathbf{M}$ & Confidence Interval \\
\hline Q1 & 32 & 46 & 78 & & \\
Q2 & 33 & 45 & 78 & 0.949 & $0.502-1.793$ \\
\cline { 1 - 4 } Total & 65 & 91 & 156 & & \\
\hline
\end{tabular}

Q1: 1. Quartile, Q2:2. Quartile

\section{Discussion}

With the commercial production of HFCS in the 1970s, fructose intake also increased significantly from $0 \mathrm{~kg}$ per capita up to $29 \mathrm{~kg}$ annually. The fructose intake from natural sources, on the other hand, has remained stable. Fructose intake in American society was classified as moderate (0-50 g/day), high (50-100 g/day) and very high (100-150 g/day) by a meta-analysis. It was reported that moderate intake of fructose has potential benefits for glycemic control while high and very high intake of fructose may lead to risks of dysglycemia and dyslipidemia (Livesey \& Taylor, 2008). A study conducted on healthy individuals determined that individuals consume about $42.3 \pm 22.73 \mathrm{~g}$ fructose received from dietary products, that men consume significantly more fructose than women and that the fructose intake of $33.3 \%$ of the individuals is $\geq 50 \mathrm{~g} /$ day (Koseler, 2011). In a study conducted with young people with type 1 diabetes, the total fructose intake was found to be $34.6 \mathrm{~g} /$ day (Couch et al., 2013). In another study, the daily fructose intake was determined to be $72.8 \mathrm{~g} /$ day (Vos et al., 2008) and in the other one is $27.9 \pm 15.7 \mathrm{~g}$ (Lamb et al., 2015). In this study, the daily fructose intake of men was found to be $13.2 \pm 12.09 \mathrm{~g}$ and that of women $13.6 \pm 11.10 \mathrm{~g}$ (Table 1). In addition, in this study daily fructose intake mostly comes from natural resources, and the daily fructose intake of the individuals can be classified as low, because the participants in this study try to consume less sugar or sugar added foods, sodas and sugar sweetened soft drinks due to their diabetic conditions. Given the fact that high dietary fructose consumption in particular is a result of the addition of HFCS into foods, it is only natural that the amount of fructose the participants in this study receive from their daily diet is low.

The ratios of fructose received from dietary energy and carbohydrates matter as much as its daily intake. A study conducted on young adults determined that $10-12 \%$ of the fructose consumed in the daily diet is received from the total energy (Park \&Yetley 1993). Another study conducted on individuals with type 1 diabetes reported that $7.9 \%$ of the fructose consumed in the daily diet is received from the total energy (Couch et al., 2013) while another study reported $12 \%$ (Vos et al., 2008). In NHANES (1999-2004) study, energy received from fructose and carbohydrates were found to be $18 \%$ and $41 \%$ (Marriott, 2009). This study determined that the ratios of the daily dietary energy received from fructose were $7.4 \pm 5.56 \%$ and $7.4 \pm 5.34 \%$ in men and women, respectively (Table 1). Given the fact that energy received from fructose should be less than 10\%, it can be asserted that these amounts are within acceptable limits. However, considering the latest recommendation of the WHO, which state that dietary sugar should account for no more than 5\% of daily calories consumed, it can be argued that the participants should reduce their daily intake of sugar further (WHO, 2015). The ratios of the daily fructose received from the total carbohydrate were $3.2 \pm 2.41 \%$ and $3.2 \pm 2.40 \%$ in men and women, respectively (Table 1). A study conducted on individuals with type 2 diabetes indicated that oral intake of low amounts of fructose increased glycogen synthesis and reduced the glycemic response (Petersen et al., 2001). 
Arslan, S., \& Sanlier, N. (2016). Relationship between daily dietary fructose intake, body composition and biochemical parameters patients with type 2 diabetes. Journal of Human Sciences, 13(2), 2642-2655. doi:10.14687/jhs.v13i2.3737

Sucrose is also an important sweetener today and an important source of fructose. A study on healthy individuals determined that they received 50.6 $\pm 33.21 \mathrm{~g}$ sucrose from their daily diet, $8.8 \%$ of the total energy from sucrose and 19.8\% from carbohydrate. Another study conducted on individuals with type 1 diabetes reported that the daily amount of sucrose received from dietary intake was 48.8 $\pm 24.3 \mathrm{~g}$ (Lamb et al,. 2015). This study determined that the amount of sucrose $(11.7 \pm 16.11 \mathrm{~g})$ the male participants received from their daily diet was lower than that $(12.4 \pm 13.95 \mathrm{~g})$ of the female participants $(\mathrm{p}>0.05)$ (Table 1$)$. The ratios of the total energy intaken from sucrose in the daily diet were $2.2 \pm 2.82 \%$ and $3.2 \pm 3.49 \%$ in men and women, respectively. This may be because although these individuals have diabetes, they use sugar in coffee and tea, and consume, though in small amounts, sugar-containing foods such as dairy desserts, honey, and jam.

Long-term consumption of foods and drinks with high fructose corn syrup leads to an increase in body weight (Schulze et al., 2004). It is argued that consumption of pure fructose or a fructose-rich diet suppresses the secretion of insulin and the production of leptin, which in turn causes weight gain (Havel, 2005). When a nutrition program in which $13 \%$ of the energy was received from beverages sweetened with fructose or from beverages sweetened with $50 \%$ glucose $+50 \%$ fructose was applied to healthy young men for 3 weeks, waist/hip ratio was reported to increase; however, the same effect was not observed when glucose-sweetened beverages were consumed (Aeberli et al., 2011). It was reported that fructose intake led to an increase in visceral adipose tissue while glucose led to an increase in subcutaneous adipose tissue (Stanhope \& Havel, 2008). Similarly, a study on healthy individuals determined that the group consisting of obese individuals had the highest daily fructose intake (Koseler, 2011). This study determined that the individuals consuming the highest levels of fructose (Q4) had higher BMI, waist circumference and visceral fat average than the individuals consuming the lowest levels of fructose (Q1). However, the difference between the two groups was not statistically significant $(\mathrm{p}>0.05)$. In this study, the fructose intake of the overweight individuals was $14.7 \pm 8.06 \mathrm{~g}$ and the levels did not show a statistically significant difference from that $(13.3 \pm 8.03 \mathrm{~g})$ of the individuals with normal BMI (Table 3). A study on individuals with diabetes failed to detect a significant association between fructose intake and BMI and the effect of daily dietary intake of fructose exceeding $50 \mathrm{~g}$ showed no statistically significant contribution to the risk of being overweight (Couch et al., 2013). It was detected that the individuals consuming the highest levels of fructose (Q4) obtained higher levels of energy, carbohydrates and protein than the individuals consuming the lowest levels of fructose (Q1) $(\mathrm{p}<0.05)$ (Table 2). Excessive fructose intake is thought to provide a positive energy balance and increase the body weight (Stanhope, 2012). Due to the fact that fructose does not stimulate insulin and leptin secretion, it is presumed that it may affect food intake and energy expenditure in the long term (Stanhope, 2012). However, studies on the effect of high fructose intake on body weight are mostly experimental studies carried out on rats, hence, case-control studies on this subject are insufficient. In this study, risk analysis calculation was made to determine the relationship between obesity and fructose intake. However, there was no statistically significant difference in terms of obesity between the groups consuming the highest and lowest levels of fructose ( $p>0.05$, Table 6$)$. This might be due to the fact that the daily dietary fructose intake of the participants was not high.

When $25 \%$ of the energy is intaken from HFCS, fructose or glucose, no development of insulin resistance has not been observed (Stanhope et al., 2011). This effect could not be found in this study perhaps because the participants were young and individuals of normal weight. A metaanalysis on fructose intake indicates that $<90 \mathrm{~g} /$ day is the safe amount and that this dose reduces HbA1c concentration and has a beneficial effect (Livesey \& Taylor 2008). In another study, $50 \mathrm{~g}$ of each glucose, sucrose and fructose was administered to each of the 9 healthy individuals, 10 individuals with impaired glucose tolerance and 12 individuals with type 2 diabetes. It was 
Arslan, S., \& Sanlier, N. (2016). Relationship between daily dietary fructose intake, body composition and biochemical parameters patients with type 2 diabetes. Journal of Human Sciences, 13(2), 2642-2655. doi:10.14687/jhs.v13i2.3737

reported in the study that fructose intake caused lower insulin response, serum glucose level and glycosuria compared to glucose and sucrose intake (Crapo et al., 1980). Diabetic patients were administered fructose instead of other carbohydrates in a different study (Cozma et al., 2012). It was observed that glycemic control was positively affected (HbA1c reduction) without insulin being affected. This positive effect is believed to be due to the fact that fructose has a low glycemic index or that fructose intake in low doses upregulates the glucokinase enzyme which shows a catalytic effect. In a 10 -week long diet in which $25 \%$ of the energy is received from fructose, de novo lipogenesis (DNL) speeds up in the liver of overweight and obese adults, but the same effect was not observed with glucose intake (Cozma et al., 2012; Stanhope et al., 2009).

While the consumption of fructose-sweetened beverages reduced glucose tolerance and insulin sensitivity of obese individuals, this effect was not observed with the consumption of glucose-sweetened beverages (Stanhope, 2012). In another study, plasma TG, TC and LDL-C levels were determined to be higher in young individuals with type 1 diabetes consuming $\geq 1$ cup of sugar-sweetened beverage (Bartsov et al., 2011). Fructose and glucose metabolisms are different from each other. Through de novo lipogenesis, fructose can develop insulin resistance as a direct source of lipid in the liver (Stanhope, 2012). The fact that fructose is quite lipogenic, stimulates the TG synthesis and increases fat accumulation in the liver through an increase in diacylglycerol and acyl coenzyme A (Stanhope \& Havel, 2008). Compared to isocaloric glucose, administration of fructose has been observed to lead more to an increase in postprandial hypertriglyceridaemia and apolipoprotein B levels (Stanhope \& Havel 2008; Swarbrick et al., 2008). In a study in which healthy individuals were administered a single dose of $50 \mathrm{~g} /$ day of fructose, fructose was observed to have a statistically significant association with an increase in TC, LDL-C and HDL-C levels, while was observed to have no significant effect on triglyceride levels (Jameel et al., 2014). The fact that the metabolism of fructose is different from that of glucose causes these effects. Unlike glucose, entry of the fructose into cells is not insulindependent and due to the lack (of rate-limiting enzymes in the metabolism of the fructose, fatty acid biosynthesis increases. In another study, it has been determined that fructose and glucose may lead to the development of type 2 diabetes (Meyer et al., 2000). In this study, it was determined that the individuals consuming the highest levels of fructose (Q4) had higher VLDL$\mathrm{C}, \mathrm{HbA1c}$ levels and lower HDL-C levels than individuals consuming the lowest levels of fructose (Q1) but the difference between the two groups was not statistically significant $(\mathrm{p}>0.05)$ (Table 2). In a study with individuals with diabetes, a statistically significant association was observed between fructose intake and serum TG levels while no statistically significant association was observed between fructose intake and TC, LDL-C and HDL-C (Couch et al., 2013). Similarly, in this study, no statistically significant association was observed between fructose intake and biochemical parameters below or above the reference value. Considering the fact that diabetic individuals are at risk for cardiovascular diseases, their blood lipids must be kept under control. Although statistically significant differences were not determined due to low fructose intake in this study, it should be taken into account that high fructose intake may generate adverse effects on blood lipids.

There are few studies on the effect of high fructose intake on body weight and the negative effects of fructose manifest themselves in experimental studies only when fructose intake is in excessive doses. Hence, this situation makes it difficult to interpret these studies as the amount of fructose people receive from their diets is lower than the excessive fructose intake in the studies. Overall, fructose was not observed to have an adverse effect on the health of the participants because the amount of fructose received by them was lower than $50 \mathrm{~g}$. Another important point worth noting is that the fructose sources of the participants in this study were natural foods instead of HFCS-sweetened beverages; therefore, the pulp, vitamins, minerals and 
Arslan, S., \& Sanlier, N. (2016). Relationship between daily dietary fructose intake, body composition and biochemical parameters patients with type 2 diabetes. Journal of Human Sciences, 13(2), 2642-2655. doi: $10.14687 /$ ihs.v13i2.3737

antioxidant content of the natural foods, despite of their fructose content, may prevent from adverse effects.

This study had several limitations. Due to some technical problems such as unwillingness of some individuals to complete the food consumption record and to take anthropometric measurements, some surveys had to be cancelled which limited the number of individuals participating in the study. Further studies that contain control groups should be carried out in order to provide more specific recommendations on fructose intake in diabetic individuals.

\section{Conclusion and recommendations}

Fructose intake in small amounts does not cause adverse health effects in people with diabetes because diabetic individuals consume fructose added foods and beverages, which are the primary sources of fructose, to a lesser extent. However, due to possible negative effects of added fructose, foods that contain high fructose corn syrup should be consumed within the limits specified. In addition, it is advisable to consume fructose from natural sources in such a way that it provides less than $10 \%$ or even $5 \%$ of the energy according to the latest recommendations. In case fructose is used as a sweetener, the amount used should be taken into account. Considering the fact that the negative effects of fructose arise mostly from the added fructose, it is important that not only diabetic individuals but also healthy individuals are careful about the consumption of such foods and individuals should even be encouraged to acquire the habit of reading food nutrition labels. However, some food nutrition labels do not always clearly provide information about the amount of fructose the food contain, which makes it difficult for people to determine the net amount of fructose they receive. Therefore, food nutrition labels should contain the information as to whether or not high fructose corn syrup was used in the production, and if so, the amount should be provided on the label.

\section{References}

Aeberli, I., Gerber, P.A., Hochuli, M., Kohler, S., Haile S,R., Gouni-Berthold, I., et al. (2011). Low to moderate sugar-sweetened beverage consumption impairs glucose and lipid metabolism and promotes inflammation in healthy young men: a randomized controlled trial. Am J Clin Nutr, 94(2): 479-485.

View Article: DOI: http://dx.doi.org/10.3945/ajcn.111.013540

Bantle, J.P., Wylie-Rosett, J., Albright, A.L., Apovian, C.M., Clark, N.G., Franz, M.J., et al. (2008). Nutrition recommendations and interventions for diabetes: a position statement of the American Diabetes Association. Diabetes Care, Suppl 1: S61-S78

View Article: DOI: http://dx.doi.org/10.2337/dc08-S061.

Basciano, H., Federico, L., \& Adeli, K. (2005). Fructose, insulin resistance, and metabolic dyslipidemia. Nutr Metab, 2(1): 5.

View Article: DOI: http://dx.doi.org/10.1186/1743-7075-2-5.

Bebis Nutrition Data Base Software Data Base. (2004). The German Food Code and Nutrient Data Base (BLS II.3, 1999) with additions from USDA-sr and other sources, İstanbul, Turkey.

Bortsov, A.V., Liese, A.D., Bell, R.A., Dabelea, D., D’Agostino, Jr R.B., Hamman, R.F., et al. (2011). Sugar-sweetened and diet beverage consumption is associated with cardiovascular risk factor profile in youth with type 1 diabetes. Acta Diabetol, 48(4): 275-282. 
Arslan, S., \& Sanlier, N. (2016). Relationship between daily dietary fructose intake, body composition and biochemical parameters patients with type 2 diabetes. Journal of Human Sciences, 13(2), 2642-2655. doi:10.14687/ihs.v13i2.3737

View Article: DOI: http://dx.doi.org/10.1007/s00592-010-0246-9.

Bray, G.A. (2008). Fructose: should we worry. Int J Obes, 32(Suppl 7): S127-S131.

View Article: DOI: http://dx.doi.org/doi:10.1038/ijo.2008.248.

Chiavaroli, L., Ha, V., Kendall, C.W., \& Sievenpiper, J.L. (2014). Is industrial fructose just a marker of an unhealthy dietary pattern? J Hepatol, 61(1): 172-173.

View Article: DOI: http://dx.doi.org10.1016/j.jhep.2014.02.008.

Couch, S.C., Crandell, J.L., Shah, A.S., Dolan, L.M., Merchant, A.T., Liese, A.D., et al. (2013). Fructose intake and cardiovascular risk factors in youth with type 1 diabetes: SEARCH for diabetes in youth study. Diabetes Res Clin Prac, 100(2): 265-271.

View Article: DOI: http://dx.doi.org/10.1016/j.diabres.2013.03.013.

Cozma, A.I., Sievenpiper, J.L., de Souza R.J., Chiavaroli, L., Ha, V., Wang, D.D., et al. (2012). Effect of fructose on glycemic control in diabetes: a systematic review and meta-analysis of controlled feeding trials. Diabetes Care, 35(7): 1611-1620.

View Article: DOI: http://dx.doi.org/10.2337/dc12-0073.

Crapo, P.A., Kolterman, O.G., \& Olefsky, J.M. (1980). Effects of oral fructose in normal, diabetic, and impaired glucose tolerance subjects. Diabetes Care, 3(5): 575-82.

Crapo, P.A., Insel, J., Sperling, M., \& Kolterman, O.G. (1981). Comparison of serum glucose, insulin, and glucagon responses to different types of complex carbohydrate in noninsulindependent diabetic patients. Am J Clin Nutr, 34(2): 184-190.

Feinman, R.D., \& Fine, E.J, 2013. Fructose in perspective. Nutr Metab (Lond), 10(1): 45.

View Article: DOI: http://dx.doi.org/10.1186/1743-7075-10-45.

Forshee, R.A., Storey, M.L., Allison, D.B., Glinsmann, W.H., Hein, G.L., Lineback, D.R., et al. (2007). A critical examination of the evidence relating high fructose corn syrup and weight gain. Crit Rev Food Sci Nutr, 47(6): 561-582.

View Article: DOI: http://dx.doi.org/10.1080/10408390600846457.

Gaby, A.R. (2005). Adverse effects of dietary fructose. Altern Med Rev, 10(4): 294-306.

Goran, M.I., Ulijaszek, S.J., \& Ventura, E.E. (2013). High fructose corn syrup and diabetes prevalence: a global perspective. Glob Public Health, 8(1): 55-64.

View Article: DOI: http://dx.doi.org/10.1080/17441692.2012.736257.

Hallfrisch, J., Ellwood, K.C., Michaelis, O.E., Reiser, S., O'Dorisio, T.M., \& Prather, E.S. (1983). Effects of dietary fructose on plasma glucose and hormone responses in normal and hyperinsulinemic men. J Nutr, 113(9): 1819-1826.

Havel, P.J. (2005). Dietary fructose: implications for dysregulation of energy homeostasis and lipid/carbohydrate metabolism. Nutr Rev, 63(5): 133-157.

View Article: DOI: http://dx.doi.org/10.1111/j.1753-4887.2005.tb00132.x.

Hossain, P., Kawar, B., \& El Nahas, M. (2007). Obesity and diabetes in the developing world-a growing challenge. $N$ EnglJ Med, 356(3): 213-215. 
Arslan, S., \& Sanlier, N. (2016). Relationship between daily dietary fructose intake, body composition and biochemical parameters patients with type 2 diabetes. Journal of Human Sciences, 13(2), 2642-2655. doi:10.14687/ihs.v13i2.3737

View Article: DOI: http://dx.doi.org/10.1056/NEJMp068177.

Jameel, F., Phang, M., Wood, L.G., \& Garg, M.L. (2014). Acute effects of feeding fructose, glucose and sucrose on blood lipid levels and systemic inflammation. Lipids Health Dis, 13: 195.

View Article: DOI: http://dx.doi.org/10.1186/1476-511X-13-195.

Johnson, R.J., Segal, M.S., Sautin, Y., Nakagawa, T., Feig, D.I., Kang, D.H., et al. (2007). Potential role of sugar (fructose) in the epidemic of hypertension, obesity and the metabolic syndrome, diabetes, kidney disease, and cardiovascular disease. Am J Clin Nutr, 86(4): 899-906.

Koseler, E. (2011). Farkh miktarlarda tüketilen fruktozun, vücut ağırllŭı ve bazı biyokimyasal parametreler ürerine etkisi. MSc thesis, Ankara: Baskent University.

Lamb, M.M., Frederiksen, B., Seifert, J.A., Kroehl, M., Rewers, M., \& Norris, J.M. (2015). Sugar intake is associated with progression from islet autoimmunity to type 1 diabetes: the Diabetes Autoimmunity Study in the Young. Diabetologia, 58(9): 2027-2034. View Article: DOI: http://dx.doi.org/10.1007/s00125-015-3657-x.

Livesey, G., \& Taylor, R. (2008). Fructose consumption and consequences for glycation, plasma triacylglycerol, and body weight: meta-analyses and meta-regression models of intervention studies. Am J Clin Nutr, 88(5): 1419-1437.

View Article: DOI: http://dx.doi.org/10.3945/ajcn.2007.25700.

Marriott, B.P., \& Cole, N., Lee, E. (2009). National estimates of dietary fructose intake increased from 1977 to 2004 in the United States. J Nutr, 139(6): 1228S-1235S.

View Article: DOI: http://dx.doi.org/10.3945/in.108.098277.

Mayes, P.A. (1993). Intermediary metabolism of fructose. Am J Clin Nutr, 58(5 Suppl):754-765.

Meyer, K.A., Kushi, L.H., Jacobs, D.R., Slavin, J., Sellers, T.A., \& Folsom, A.R. (2000). Carbohydrates, dietary fiber, and incident type 2 diabetes in older women. Am J Clin Nutr, 71(4): 921-930.

Neilson, E.G. (2007). The fructose nation. J Am Soc Nephrol, 18(10): 2619-2621. View Article: DOI: http://dx.doi.org/10.1681/ASN.2007070750.

Park, Y.K., \& Yetley, E.A. (1993). Intakes and food sources of fructose in the United States. Am J Clin Nutr, 58(5 Suppl): 737S-747S.

View Article: DOI: http://dx.doi.org10.1681/ASN.2007070750.

Pekcan, G. (2008). Beslenme durumunun saptanması. In: Baysal A (Ed.): Diyet el kitabr. $5^{\text {th }}$ ed. Hatipoğlu Yayınevi, Ankara, pp.97-118.

Petersen, K.F., Laurent, D., Yu, C., Cline, G.W., \& Shulman, G.I. (2001). Stimulating effects of low-dose fructose on insulin-stimulated hepatic glycogen synthesis in humans. Diabetes, 50(6): 1263-1268.

View Article: DOI: $\underline{\text { http://dx.doi.org/10.2337/diabetes.50.6.1263. }}$ 
Arslan, S., \& Sanlier, N. (2016). Relationship between daily dietary fructose intake, body composition and biochemical parameters patients with type 2 diabetes. Journal of Human Sciences, 13(2), 2642-2655. doi:10.14687/jhs.v13i2.3737

Poitout, V., Robertson, R.P. (2008). Glucolipotoxicity: fuel excess and $\beta$-cell dysfunction. Endocr Rev, 29(3): 351-366.

View Article: DOI: http://dx.doi.org/10.1210/er.2007-0023.

Rakicioglu, N., Acar, N.T., Ayaz, A., \& Pekcan, G. (2012). Yemek ve besin ve fotoğraf kataloğu: Ölçü ve miktarlar. 3th ed. Ata offset publications, Ankara.

Schulze, M.B., Manson, J.E., Ludwig, D.S., Colditz, G.A., Stampfer, M.J., Willett, W.C. et al. (2004). Sugar-sweetened beverages, weight gain, and incidence of type 2 diabetes in young and middle-aged women. JAMA, 292(8): 927-934.

View Article: DOI: http://dx.doi.org/10.1001/jama.292.8.927.

Sheehy, A.M., Coursin, D.B., \& Gabbay, R.A. (2009). Back to Wilson and Jungner: 10 good reasons to screen for type 2 diabetes mellitus. Mayo Clin Proc, 84(1): 38-42.

View Article: DOI: http://dx.doi.org/10.1016/S0025-6196(11)60806-9.

Simonson, D.C., Tappy, L., Jequier, E., Felber, J.P., DeFronzo, R.A. (1988). Normalization of carbohydrate-induced thermogenesis by fructose in insulin-resistant states. Am J Physio, 254(2 Pt 1): E201-207.

Stanhope, K.L., \& Havel, P.J. (2008). Fructose consumption: potential mechanisms for its effects to increase visceral adiposity and induce dyslipidemia and insulin resistance. Curr Opin Lipidol, 19(1): 16-24.

View Article: DOI: http://dx.doi.org/10.1097/MOL.0b013e3282f2b24a.

Stanhope, K.L., Schwarz, J.M., Keim, N.L., Griffen, S.C., Bremer, A.A., Graham, J.L., et al. (2009). Consuming fructose-sweetened, not glucose-sweetened, beverages increases visceral adiposity and lipids and decreases insulin sensitivity in overweight/obese humans. J Clin Invest, 119(5): 1322-1334.

View Article: DOI: http://dx.doi.org/10.1172/JCI37385.

Stanhope, K.L., Bremer, A.A., Medici, V., Nakajima, K., Ito, Y., Nakano, T., et al. (2011). Consumption of fructose and high fructose corn syrup increase postprandial triglycerides, LDL-cholesterol, and apolipoprotein-B in young men and women. J Clin Endocrinol Metab, 96(10): E1596-1605.

View Article: DOI: http://dx.doi.org/10.1210/jc.2011-1251.

Stanhope, K.L. (2012). Role of fructose-containing sugars in the epidemics of obesity and metabolic syndrome. Annu Rev Med, 63: 329-343.

View Article: DOI: http://dx.doi.org/10.1146/annurev-med-042010-113026.

Stephan, B.C.M., Wells, J.C.K., Brayne, C., Albanese. E., \& Siervo, M. (2010). Increased fructose intake as a risk factor for dementia. J Gerontol A Biol Sci Med Sci, 65(8): 809-814.

View Article: DOI: http://dx.doi.org/10.1093/gerona/glq079.

Swarbrick, M.M., Stanhope, K.L., Elliott, S.S., Graham, J.L., Krauss, R.M., Christiansen, M.P., et al. (2008). Consumption of fructose-sweetened beverages for 10 weeks increases postprandial triacylglycerol and apolipoprotein-B concentrations in overweight and obese women. B J Nutr, 100(5): 947-952.

View Article: DOI: http://dx.doi.org/10.1017/S0007114508968252. 
Arslan, S., \& Sanlier, N. (2016). Relationship between daily dietary fructose intake, body composition and biochemical parameters patients with type 2 diabetes. Journal of Human Sciences, 13(2), 2642-2655. doi:10.14687/jhs.v13i2.3737

Tappy, L., Randin, J., Felber, J., Chiolero, R., Simonson, D., Jequier E, et al. (1986). Comparison of thermogenic effect of fructose and glucose in normal humans. Am J Physiol, 250(6 Pt 1): $718-24$.

Vos, M.B., Kimmons, J.E., Gillespie, C., Welsh, J., \& Blanck, H.M. (2008). Dietary fructose consumption among US children and adults: the Third National Health and Nutrition Examination Survey. Medscape J Med, 10(7): 160.

Wang, D.D., Sievenpiper, J.L., de Souza, R.J., Chiavaroli, L., Ha, V., Cozma, A.I., et al. (2012). The effects of fructose intake on serum uric acid vary among controlled dietary trials. $J$ Nutr, 142(5): 916-923.

View Article: DOI: http://dx.doi.org/10.3945/jn.111.151951.

White, J.S. (2013). Challenging the fructose hypothesis: new perspectives on fructose consumption and metabolism. Adv Nutr, 4(2): 246-256.

View Article: DOI: http://dx.doi.org/10.3945/an.112.003137.

WHO. (2000). Obesity: preventing and managing the global epidemic. Geneva: World Health Organization.

WHO. (2015). Guideline: Sugars intake for adults and children. Geneva: World Health Organization. 